\title{
Periapical Tissue Healing after Post Space Preparation with or without Use of a Protection Plug and Root Canal Exposure to the Oral Environment. Study in Dogs
}

\author{
Roberto HOLLAND ${ }^{1,2}$ \\ Luciana Noronha MANNE ${ }^{2}$ \\ Valdir de SOUZA ${ }^{1,2}$ \\ Sueli Satomi MURATA ${ }^{2}$ \\ Eloi DEZAN JÚNIOR ${ }^{1}$ \\ ${ }^{1}$ Discipline of Endodontics, Department of Restorative Dentistry, School of Dentistry of Araçatuba, \\ São Paulo State University, Araçatuba, SP, Brazil \\ ${ }^{2}$ Postgraduate Program in Endodontics, School of Dentistry, University of Marilia, Marília, SP, Brazil
}

\begin{abstract}
The purpose of this study was to evaluate the influence of coronal leakage on the healing of dogs' periapical tissues after root canal filling, post space preparation and protection or not with a temporary sealer plug. Forty root canals of dogs' teeth were instrumented and filled by the lateral condensation technique with gutta-percha points and Endomethasone or CRCS sealers. After post space preparation, the remaining filling material was protected or not with a plug of temporary Coltosol sealer and exposed to the oral environment for 90 days. Thereafter, the animals were sacrificed and the specimens were removed and prepared for histomorphological and histobacteriological analysis. The findings revealed $35 \%$ of microbial leakage in the groups without plugs and $15 \%$ of leakage in the groups with plugs. Statistical analysis showed that the use of a Coltosol plug improved significantly the histomorphological results regardless of the type of root canal sealer $(\mathrm{p}=0.05)$ and that CRCS and Endomethasone sealers showed similar results $(\mathrm{p}>0.05)$.
\end{abstract}

Key Words: coronal leakage, root canal sealer, post space preparation, periapical repair, root canal therapy.

\section{INTRODUCTION}

The success of endodontic treatment is strictly related to the elimination of etiologic factors of periapical problems from the root canal system allied to a hermetic sealing of the space created during biomechanical preparation using a filling material with excellent physical and biological properties.

Nevertheless, most studies evaluating the sealing efficiency of root canal fillings have investigated leakage through the root apex. According to Khayat et al. (1), recontamination of a filled root canal through the crown, allowing microorganisms to reach the periapical tissues, can occur in cases of exposure of the filling material to the oral environment, in the following situations: a. tooth decay; $b$. failure, loss or fracture of the restorative material; c. loss of temporary sealing due to delay for placement of the definitive restoration; $d$. contamination during the restorative procedures. This observation has led some authors to analyze the efficiency of coronal sealing of root canal fillings $(2,3)$. Several in vitro studies have been conducted employing different tracer agents. Torabinejad et al. (4) mentioned that microorganisms can invade the coronal portion of root canal fillings, reaching the apical portion in nearly 30 days, even in well filled root canals.

Correspondence: Prof. Dr. Roberto Holland, Departamento de Odontologia Restauradora, Faculdade de Odontologia de Araçatuba, UNESP, Rua José Bonifácio, 1193, 16015-050 Araçatuba, SP, Brasil. Tel.: +55-18-3636-3278. Fax: +55-18-3636-3332. e-mail: rholland@foa.unesp.br 
Several studies have been conducted on this issue, although greater interest has been devoted to the problem of marginal coronal leakage in cases of canals submitted to post space preparation. For this reason, according to Barbosa et al. (5), coronal leakage could reach the periapical tissues in totally filled canals, which would be more evident in the followings situations: 1.after post space preparation, due to the smaller extension of the remaining material; 2 .due to poor adaptation of the filling material to the root canal walls during post space preparation; 3.due to contamination of the canal portion from which the obturation was removed during impression procedures and post placement. Thus, some authors have investigated the protection offered by the different types of root canal sealer, as well as by the placement of a protection plug over the remaining filling material after post space preparation, made from different materials, such as Coltosol (6) and Lumicon (5).

Marginal coronal leakage after post space preparation is a great problem for endodontic treatment and all efforts should be directed to its elimination. Specific studies addressing this issue are very important to improve the understanding of the problem and treatment possibilities. However, there is a lack of studies discussing the magnitude of the problem or its resolution by in vivo interventions. In vivo studies are of key importance because the oral conditions could influence the quality of the sealing provided by the tested materials.

In view of this, the purpose of this study was to evaluate the influence of marginal coronal leakage on the healing of dogs' periapical tissues after root canal filling, post space preparation and protection or not with a temporary sealer plug.

\section{MATERIAL AND METHODS}

The sample comprised 40 roots of incisors and premolars of two dogs aged approximately 1 year, which received previous intramuscular anesthesia with $2 \mathrm{~mL}$ of a 1:1 mixture of Ketamine-S (Cristália Produtos Químicos Farmacêuticos Ltda, Itapira, SP, Brazil) and Acepran 1\% (Univet S/A Industria Veterinária, São Paulo, SP, Brazil), followed by intravenous general anesthesia with hypnol solution (sodium pentobarbital $3 \% ; 1 \mathrm{~mL} / \mathrm{kg}$ of body weight). When necessary, this dose was complemented to keep the anesthetic effect throughout the operative period.

After extraoral antisepsis with polyvinylpirrolidone
( $1 \%$ iodine) and intraoral antisepsis with $0.12 \%$ chlorhexidine (Periogard; Colgate-Palmolive, Division of Kolynos do Brasil Ltda, Osasco, SP, Brazil), rubber dam was placed and the teeth were submitted to coronal opening with a \#1090 cylindrical diamond bur at high speed under air-water cooling. Shortly after pulp extirpation, the root canals were instrumented according a crown-down technique. Subsequently, the root canals were filled by the lateral condensation technique with gutta-percha points and the following sealers: calciobiotic root canal sealer (CRCS; Hygienic, Rio de Janeiro, RJ, Brazil), which is a calcium hydroxide-based material and Endomethasone (Specialites Septodont, Saint-Maur, France), which contains zinc oxide and eugenol. Immediately after completion of root canal filling, post space preparation was performed with \#3 Gates Glidden drills, leaving $5 \mathrm{~mm}$ of filling material in length in the groups without a protection plug of temporary sealer. The canals receiving this protection plug had the length of the remaining filling reduced to $4 \mathrm{~mm}$ in order to accommodate a 1-mm-thick plug of Coltosol temporary sealer (Vigodent S/A Industria e Comércio, Rio de Janeiro, RJ, Brazil). The following study groups were formed, with 10 specimens each: I - canals filled with CRCS sealer and immediate post space preparation, with $5 \mathrm{~mm}$ of remaining filling material; II - canals filled with Endomethasone sealer and immediate post space preparation, with $5 \mathrm{~mm}$ of remaining filling material; III - canals filled with CRCS sealer and immediate post space preparation, with $4 \mathrm{~mm}$ of remaining filling material and a 1-mm-thick protection plug of Coltosol; IV - canals filled with Endomethasone sealer and immediate post space preparation, with $4 \mathrm{~mm}$ of remaining filling material and a 1-mm-thick protection plug of Coltosol.

The root canals were then exposed to the oral environment for a period of 90 days, after which the animals were killed by an overdose of 3\% sodium pentobarbital. The jaws were sectioned and fixed in $10 \%$ buffered formalin solution at neutral $\mathrm{pH}$ for $48 \mathrm{~h}$. Subsequently, the specimens were decalcified in formic acid-sodium citrate solution, embedded in paraffin and serially sectioned longitudinally to obtain 6 - $\mu$ m-thick cuts. Some sections were stained with hematoxylin and eosin for histomorphological examination and some were stained with the Brown and Brenn method for histomicrobiological evaluation.

Histomorphological analysis of the results was 
conducted considering the following histomorphological parameters: thickness and extension of newly formed cementum; biological closure of the apical delta; apical cementum and bone tissue; acute and chronic inflammatory infiltrate (intensity and extension); thickness and organization of periodontal ligament; presence of microorganisms; limit of filling and presence of remnants. These histomorphological parameters received scores 1 to 4,1 being the best result and 4 the worst, with intermediate outcomes for scores 2 and 3 (7). Data were submitted to statistical analysis by Kruskal Wallis and Mann-Whitney tests. Significance level was set at 5\%.

\section{RESULTS}

\section{CRCS Without Plug}

In all specimens, except for one case, the filling material was restricted to the root canal space close to the canal dentin junction (CDJ). All specimens but one presented debris that, in most cases, impaired the contact of the filling material with the more coronal portion of pulp stumps. In half specimens, the pulp stumps presented biological closure by cementum deposition on its more coronal portion or even near the foramen, mainly when the pulp stumps were in contact with dentin debris, except for 4 cases. In the other specimens, the morphological aspect of pulp stump tissue suggested vitality. The most coronal portion of the pulp stumps exhibited vitality, newly formed cementum or even necrosis. Neutrophil infiltrate occurred in 4 cases, with variable intensity and extension limited to the pulp stump or slightly extending to periodontal ligament.

In general, the periodontal ligament was partially organized, with a mean thickness of $330 \mu \mathrm{m}$. Except for 1 case, all other specimens revealed chronic inflammatory infiltrate of mild intensity in 5 cases and moderate or severe in 4 cases (Fig. 1). Four specimens further presented neutrophil infiltrate, especially at the apical root canal third. In some cases, newly formed cementum covered the pre-existing periapical cementum, with a mean thickness of $4 \mu \mathrm{m}$. Only one case showed an non-repaired area of resorption of pre-existing cementum. The bone tissue showed areas of active or nonrepaired resorption in most cases.

The Brown and Brenn staining showed presence of Gram-positive and Gram-negative microorganisms in 4 cases, lodged in the dentinal tubules and apical delta canals, as well as inside cementoplasts (Fig. 2).

\section{Endomethasone Without Plug}

In all specimens, the filling material reached the CDJ and there were debris primarily composed of dentin debris and organic residues. These debris could totally or partially impede the contact of the sealer with the pulp stumps. Sometimes, contact with the sealer led to partial or total pulp stump necrosis. In some cases, contact of the pulp stump with the dentin debris was

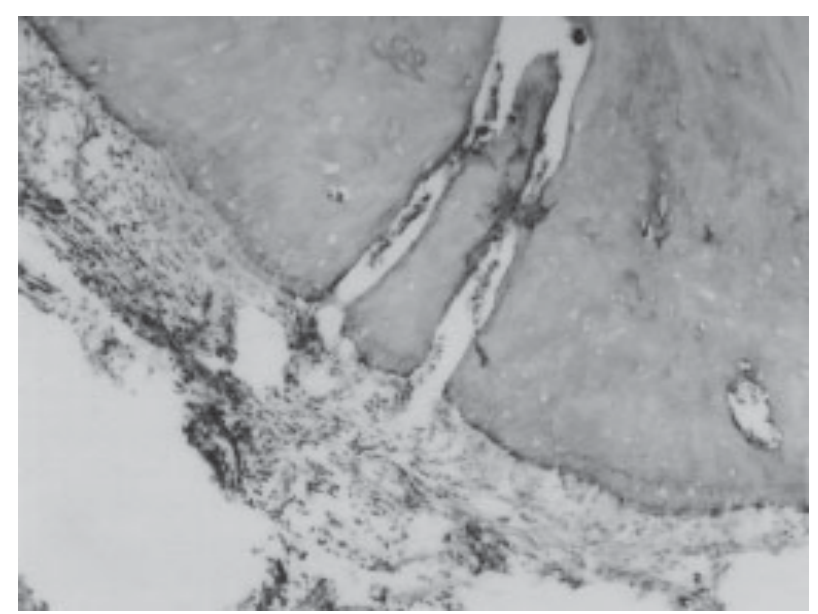

Figure 1. CRCS without plug: Note necrotic pulp stumps and periodontal ligament with moderate chronic inflammatory reaction. $\mathrm{HE}$ (original magnification $\times 100$ ).

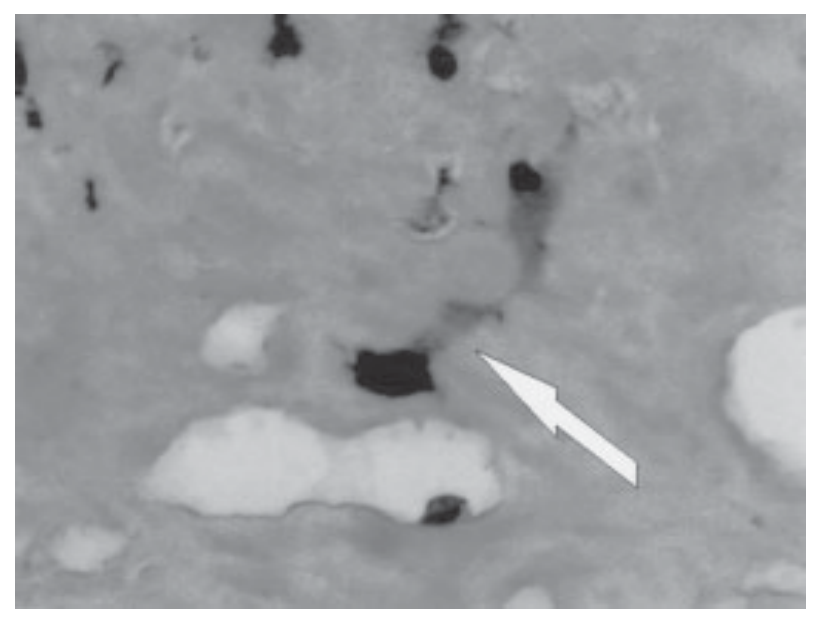

Figure 2. CRCS without plug: Presence of Gram-positive and Gram-negative microorganisms in the cementum (arrow). Brown and Brenn staining (original magnification $\times 200$ ). 
related to cementum deposition, leading to biological closure. Biological closure of most part of the pulp stump by newly formed cementum was observed in 3 cases. Six specimens did not display sealing and 1 case exhibited only limited sealing.

The periodontal ligament was well organized in 1 case, totally disorganized in 2 cases and partially organized in the others, with a mean thickness of $311 \mu \mathrm{m}$. Neutrophil infiltrate was observed only in 3 cases; lymphocytes, plasma cells and histiocytes were observed in 8 specimens, with variable intensity and extension (Fig. 3). Newly formed cementum covering the pre-existing apical cement or repairing a small area of resorption was observed in 8 cases, showing a thin layer with a mean thickness of $5 \mu \mathrm{m}$.

Most cases showed areas of completely repaired resorption of the pre-existing cement or absence of resorption and 3 cases had areas of non-repaired resorption. Only 3 cases revealed areas of active or nonrepaired bone resorption.

The Brown and Brenn staining showed presence of Gram-positive and Gram-negative microorganisms in 3 specimens. These microorganisms were located close to the CDJ, adjacent to dentinal tubules and inside cementoplasts (Fig. 4).

\section{CRCS With Plug}

In all cases, the more apical portion of the filling

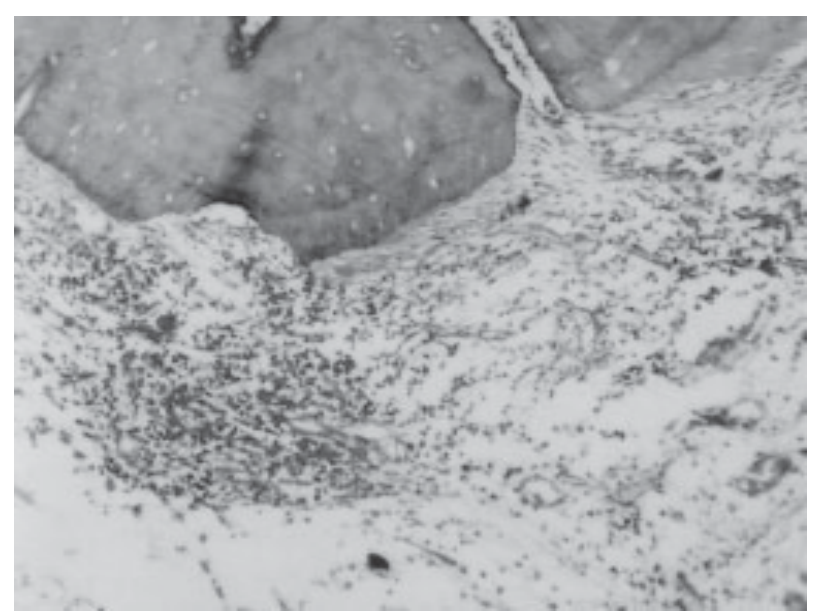

Figure 3. Endomethasone without plug. Cementum resorption and acute and chronic inflammatory cells in the periodontal ligament. HE (original magnification $\times 100$ ). material was close to or at the CDJ, except for 2 cases. The other specimens presented debris, basically composed of dentin debris and organic residues at the most apical portion of the root canal, impeding or not the contact of the filling material with the pulp stumps. Except for 4 specimens, the others exhibited presence of biological closure by newly formed cementum and most of them presented morphological aspect suggestive of vitality (Fig. 5). These pulp stumps often showed necrosis at the most coronal portion, with an underlying area of chronic inflammatory infiltrate, with presence of neutrophils in only 2 cases.

The periodontal ligament was totally disorganized in 1 case and partially organized in the others, with a mean thickness of $298 \mu \mathrm{m}$. Two specimens did not display inflammatory infiltrate, while the others displayed lymphocytes, plasma cells and histiocytes in variable intensity and extension, with neutrophils in only three. There was newly formed cementum with thickness ranging from 4 to $7 \mu \mathrm{m}$ covering the pre-existing cementum at the apical region in most specimens. Only 1 case showed an area of non-repaired resorption. All specimens presented areas of inactive or partially repaired bone resorption.

The Brown and Brenn staining detected the presence of Gram-positive microorganisms in only 1 specimen, together with debris at the coronal portion of the pulp as well as within the dentinal tubules at this region.

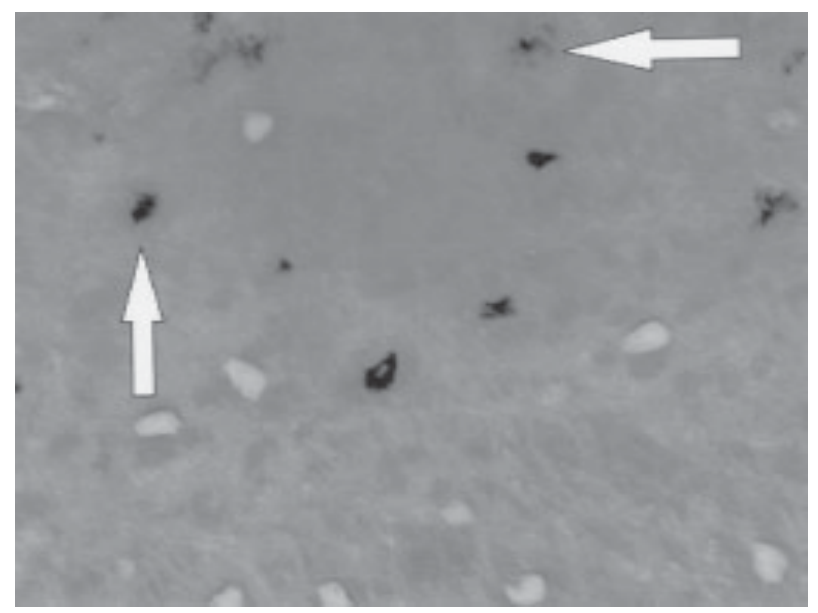

Figure 4. Endomethasone without plug. Presence of Grampositive and Gram-negative microorganisms in the cementum tissue (arrows). Brown and Brenn. (original magnification $\times 200$ ). 


\section{Endomethasone With Plug}

The filling material was restricted to the CDJ, with or without contact with the coronal portion of the pulp stumps, due to the location of debris, present in 7 cases.

Some pulp stumps in direct contact with the sealer exhibited necrosis of the most coronal portion. Except for 3 cases, all others revealed some pulp stumps with biological closure by deposition of newly formed cementum.

The periodontal ligament was well organized in 3 cases and partially or totally disorganized in the others, with a mean thickness of $387 \mu \mathrm{m}$. Chronic inflammatory infiltrate of variable intensity and extension was observed in 9 cases (Fig. 6). Two specimens also presented neutrophil infiltrate.

A thin layer of newly formed cementum, with a mean thickness of $4 \mu \mathrm{m}$, was observed in 9 cases, covering the pre-existing apical cement or even repairing a small area of resorption. One specimen revealed small areas of non-repaired cementum resorption and 7 cases exhibited inactive or partially repaired areas of bone resorption.

The Brown and Brenn staining identified the presence of Gram-positive and Gram-negative microorganisms in 2 specimens at the CDJ and inside the dentinal tubules, apical canals and cementum foramina.

The average scores attributed to the evaluated

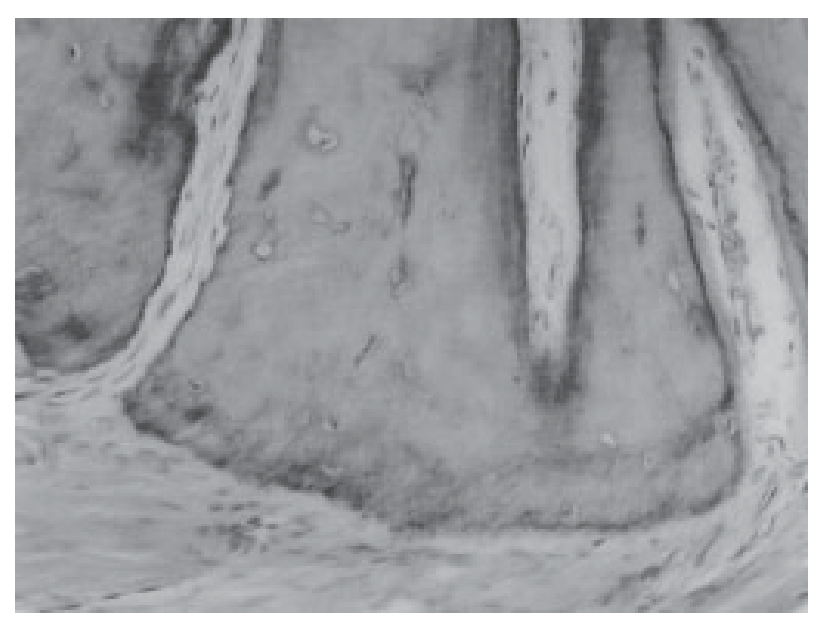

Figure 5. CRCS with plug. Pulp stumps exhibiting signs of vitality and absence of inflammatory reaction. HE (original magnification $\times 100$ ). histomorphometrical parameters in the 4 experimental groups are presented in Table 1.

\section{Statistical Analysis}

The application of Mann-Whitney test to the sealer data showed that, in general, the CRCS and Endomethasone exhibited similar results, regardless of the use of the plug $(\mathrm{p}>0.05)$. Regarding the analysis of the influence of the plug, regardless of the sealer used, there was statistically significant difference when a protective pulg was placed $(\mathrm{p}=0.05)$. Overall, Kruskal Wallis test for the treatments performed showed no significant difference between the 4 study groups $(p>0.05)$.

\section{DISCUSSION}

Although the coronal leakage of microorganisms has been shown in several in vitro studies, as already exposed, it is unquestionable the importance of investigating this issue by in vivo studies, mainly focusing on the the several variables surrounding this occurrence. The coronal leakage after post space preparation was studied in vivo in dogs' teeth (5). It was shown that the type of sealer and the use of a protection plug can influence the result. However, it must be considered that sealer quality and other characteristics relating not only to the sealers, but also to materials used as plugs, can

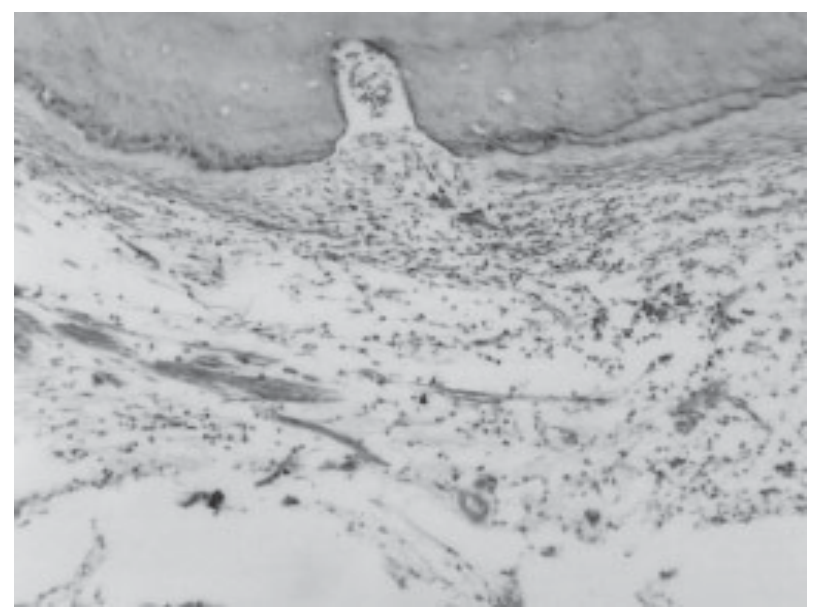

Figure 6. Endomethasone with plug. Periodontal ligament with the presence of chronic inflammatory cells. HE (original magnification $\times 100$ ). 
change considerably.

From the present results, the most important and statistically significant $(\mathrm{p}=0.05$ ) was related to analysis of the influence of using or not of a protection plug on the remaining filling. In general, the use of a plug made from Coltosol temporary sealer provided better results, regardless of the root canal sealer employed.

Several authors have reported the good sealing quality of Coltosol compared to other sealers by dye leakage $(5,8)$. However, the placement of the plug provided better overall results. In general, out of 40 treated roots, there was microbial leakage in 7 specimens in the absence of plug and 3 cases when it was used. Evidently, the presence of microorganisms strongly affected the repair of periapical tissues. This difference was not more expressive because of the postoperative time, which was only 90 days. If a longer postoperative time had been used, probably the reflexes on the periapical tissues would have been more significant.

The root canal sealers used in the present studyshould be analyzed under different aspects regarding their influence on the results, e.g. sealer properties, biological properties and antibacterial activity.

Endomethasone has been object of studies that compared its sealing capacity to that of other sealers (9), providing, in general, a good sealing. However, considering all specimens examined in this study, it was noticed that there was moderate penetration of microorganisms in $25 \%$ of cases.

When CRCS was employed, there was only 1 case of microbial leakage in the study group with plug and 4 cases when the plug was not used. The literature has shown some divergent results. While some studies state that the sealing ability of CRCS is similar to that of Sealapex $(10,11)$, another author (12) has reported that Sealapex provides a slightly better sealing than CRCS.

One factor that could contribute to reduce the microorganisms' access to the pulp stumps would be the occurrence of complete biological closure by newly formed cementum (13). However, when CRCS was used, no specimen exhibited complete biological closure of the apical pulp stump. The absence of biological closure may have occurred by the presence of debris between the sealer and the coronal surface of the pulp stump, or even because CRCS did not have the property to stimulate this occurrence.

In the root canals filled with Endomethasone, the presence of debris at the CDJ often prevented a close contact of the sealer with the coronal surface of the pulp stumps, which resulted in necrosis in some cases.

Table 1. Score means recorded in the studied experimental groups.

\begin{tabular}{|c|c|c|c|c|}
\hline Experimental groups & $\begin{array}{c}\text { CRCS } \\
\text { without plug }\end{array}$ & $\begin{array}{c}\text { Endomethasone } \\
\text { without plug }\end{array}$ & $\begin{array}{c}\text { CRCS } \\
\text { with plug }\end{array}$ & $\begin{array}{c}\text { Endomethasone } \\
\text { with plug }\end{array}$ \\
\hline Newly formed cement thickness & 3.0 & 3.0 & 3.0 & 3.0 \\
\hline Newly formed cement extension & 1.3 & 1.6 & 1.3 & 1.3 \\
\hline Biologic closure of apical delta canals & 3.4 & 3.3 & 3.2 & 3.1 \\
\hline Cement resorption & 1.2 & 1.6 & 1.2 & 1.2 \\
\hline Bone tissue resorption & 2.8 & 2.1 & 2.4 & 1.9 \\
\hline Presence of microorganism & 2.2 & 1.9 & 1.3 & 1.6 \\
\hline \multicolumn{5}{|l|}{ Acute inflammatory reaction } \\
\hline Intensity & 1.5 & 1.4 & 1.2 & 1.3 \\
\hline Extension & 1.6 & 1.3 & 1.2 & 1.3 \\
\hline \multicolumn{5}{|l|}{ Acute inflammatory chronic } \\
\hline Intensity & 2.5 & 2.4 & 2.3 & 2.4 \\
\hline Extension & 2.8 & 2.7 & 2.3 & 2.7 \\
\hline Periodontal ligament thickness & 3.0 & 2.7 & 2.6 & 2.5 \\
\hline Periodontal ligament organization & 2.8 & 2.5 & 2.8 & 2.5 \\
\hline Filling limit & 1.1 & 1.0 & 1.0 & 1.0 \\
\hline Debris & 2.0 & 2.2 & 2.0 & 1.9 \\
\hline Average of the scores & 2.22 & 2.12 & 1.98 & 1.97 \\
\hline
\end{tabular}


On the other hand, even though the debris at the CDJ could prevent the contact of the sealer with the pulp stumps, this could stay in close contact with the debris, often composed almost exclusively by dentin debris. As it is known, dentin debris have osteogenic proteins that can stimulate the new formation of hard tissue and, in the case of the pulp stumps, deposition of cementum. In the present work, there was also biological closure in some cases when in contact with dentin debris. Therefore, in the present case, the apical condensation of dentin debris was accidental, which made these dentin debris to be often accompanied by organic debris, whose presence apparently impaired the exclusive contact of the pulp stumps with the dentin debris. No case presented overfilling of sealer to the periodontal ligament. This way, there was no reaction of the connective tissue in the periodontal ligament in direct contact with the investigated sealer, but only of the pulp stumps.

CRCS has been investigated in a series of studies that analyzed its biological and cytotoxic properties $(14,15)$, revealing several divergences in outcomes in relation to these properties. This may be attributed to different methodologies, interpretations of results, etc. In the present study, the group with plug had presence of microorganisms in only one case. Thus, in this study group the observed outcomes at the periapical tissues may be related with the clinical procedures employed, combined to the behavior of the pulp stumps related to the direct contact with the filling material or with debris. Few pulp stumps exhibited biological closure by newly formed cementum. This would usually occur if it was in contact with dentin debris. As previously discussed, undoubtedly, the presence of debris at the CDJ, in almost all cases, was an outstanding variable in this study.

An observation called the attention in the study groups: the occurrence of acute inflammatory infiltrate. Neutrophil infiltrate was observed in 11 species, 10 of which also showed microorganisms leakage. Only 1 specimen had neutrophil infiltrate without presence of microorganisms, as detected by the Brown and Brenn technique. It must be considered that only some sections were stained by this technique, while the others were stained with hematoxylin and eosin. It is possible that histological sections that would show the microorganisms coincidentally were not stained by the Brown and Brenn method. The observed reaction may also have been triggered by other irritating agent besides the microorganism, such as the bacterial toxin itself.

Some assign to the CRCS the ability to stimulate the new formation of cementum, leading to achievement of biological closure by this calcium hydroxidebased material. It does not apply to Endomethasone. However, the occurrence of biological closure at apical canals was mildly expressive for both evaluated sealers.

In the present study, no significant difference was observed when all results obtained for both types of sealers were compared. Also, there was no significant difference between groups with and without plug filled with the same root canal sealer. However, in an overall comparison of the results, not considering the type of sealer, the use of the protection plug provided better results.

\section{RESUMO}

O propósito deste trabalho foi avaliar a influência da infiltração coronária no reparo dos tecidos periapicais após obturação dos canais radiculares, preparo para pino e proteção ou não de um "plug" de cimento temporário. Quarenta canais de dentes de cães foram instrumentados e obturados pela técnica da condensação lateral ativa com cones de guta-percha e os cimentos Endomethasone e CRCS. Após preparo para pino os remanescentes do material obturador foram protegidos ou não com um "plug" do cimento temporário Coltosol e expostos ao meio oral por 90 dias. Decorrido este período, os animais foram mortos e os espécimes foram removidos e preparados para análises histomorfológica e histobacteriológica. Foi observado $35 \%$ de casos de infiltração bacteriana nos grupos sem "plug" e $15 \%$ nos grupos com "plug". Concluiu-se estatisticamente que o "plug" de Coltosol foi eficiente no controle da infiltração coronária de microorganismos $(p=0,05)$, e que os cimentos CRCS e Endomethasone apresentaram resultados semelhantes $(p>0,05)$.

\section{REFERENCES}

1 Khayat A, Lee S, Torabinejad M. Human saliva penetration of coronally unsealed obturated root canals. J Endod 1993;19:458-461.

2 Alves JA, Walton RE, Drake DR. Coronal leakage: Endotoxin penetration from mixed bacterial communites through obturated post-prepared root canals. J Endod 1998;24:587-591.

3 Madison S, Swanson K, Chiles SA. An evaluation of coronal microleakage in endodontically treated teeth. Part II. Sealer types. J Endod 1987;13:109-112.

4 Torabinejad M, Ung B, Kettering JD. In vitro bacterial penetration of coronally unsealed endodontically treated teeth. J Endod 1990;16:566-569.

5 Barbosa HG, Holland R, Souza V, Dezan Junior E, Bernabé PFE, Otoboni Filho JA, Nery MJ. Healing process of dog teeth after post space preparation and exposition of the filling material to the oral environment. Braz Dent $J$ 2003;14:103-109. 
6 Holland R, Murata SS, Silva MN, Dezan Junior E, Souza V, Bernabé PFE. Influence of the sealer and a plug in coronal leakage after post space preparation. J Appl Oral Sci 2004; 12:223-226.

7 Holland R, Sant'anna Junior A, Souza V, Dezan Junior E, Otoboni Filho JA, Bernabé PFE, Nery MJ, Murata SS. Influence of apical patency and filling material on healing process of dogs' teeth with vital pulp after root canal therapy. Braz Dent J 2005;16:9-16.

8 Zaia AA, Nakagawa R, De Quadros I, Gomes BPFA, Ferraz CCR, Teixeira FB, Souza-Filho FJ. An in vitro evaluation of four materials as barriers to coronal microleakage in rootfilled teeth.Int Endod J 2002;35:729-734.

9 Sem BH, Piskin B, Baran N. The effect of tubular penetration of root canal sealers on dye microleakage. Int Endod $\mathrm{J}$ 1996;29:23-28.

10 Jacobsen EL, Begole EA, Vitkus DD, Daniel JC. An evaluation of two newly formulated calcium hydroxide cements: a leakage study. J Endod 1987;13:164-169.

11 Rothier A, Leonardo MR, Bonetti Filho I, Mendes AJ. Leakage evaluation in vitro of two calcium hydroxide and two zinc oxide - eugenol - based sealers. J Endod 1987;13:336-338.

12 Holland R, Murata SS, Souza V, Lopes HP, Saliba O. Evaluation of the apical seal produced by four calcium hydroxide sealers (Original article in Portuguese). Rev Assoc Paul Cir Dent 1996;50:61-64.

13 Holland R, Cruz A, Souza V, Nery MJ, Bernabé PFE, Otoboni Filho JA, Dezan Junior E. Comportamiento de los tejidos periapicales frente a la exposición de la obturación endodóntica al medio oral. Estudio histologico en dientes de perros. Rev Esp Endodoncia 2000;18:99-108.

14 Economides N, Kotsaki V, Poulopolos A, Kolokuris I, Rozos G, Shore R. Experimental study of the biocompatibility of four root canal sealers and their influence on the zinc and calcium content of several tissues. J Endod 1995;21:122-127.

15 Leonardo MR, Silva LA, Utrilla LS, Assed S, Ether SS. Calcium hydroxide root canal sealers: histopathologic evaluation of apical and periapical repair after endodontic treatment. $\mathrm{J}$ Endod 1997;23:428-432. 